\title{
Research on the Willingness of Farmers' Increasing Land Scale under the Financial Support
}

\author{
Zhang Dehua \\ Institute of Finance \\ Harbin University of Commerce \\ Harbin, China, 150028 \\ e-mail: zdh19841027@163.com
}

\begin{abstract}
The farmers' land scale has become the main factors of farmers' income. In the background of the financial support, the willingness and behavior of farmers to land transfer has a significant impact on the scale operation. Based on research data, through logistic regression models this paper explores the factors of farmers' land inflow behavior and provides policy reference for land appropriate scale of operations. The results show that 10 factors including the burden of the number of children have a positive impact on the growth of farmers' land operation scale and 8 factors including the head of household age are not conducive to the growth of farmers' land scale.

Keywords- financial support; farmers; land scale; moderate; factors
\end{abstract}

\section{MODEL SELECTION}

Since this research focuses on the behavior of the dependent variable is whether or not the wishes of choice for analysis, namely $\mathrm{Y}=0$ or $\mathrm{Y}=1$. And the arguments of both continuous variables, also orders the number of variables. So to choose logistic regression model for analysis, specific model is as follows:

$$
\begin{gathered}
P\left(y=1 \mid x_{1}, x_{2}, \cdots x_{n}\right)=\frac{e^{\beta_{0}+\sum_{i=1}^{n} \beta_{i} x_{i}}}{1+e^{\beta_{0}+\sum_{i=1}^{n} \beta_{i} x_{i}}} \\
1-P=P\left(y=0 \mid x_{1}, x_{2}, \cdots x_{n}\right)=\frac{1}{1+e^{\beta_{0}+\sum_{i=1}^{n} \beta_{i} x_{i}}} \\
\frac{P}{1-P}=e^{\beta_{0}+\sum_{i=1}^{n} \beta_{i} x_{i}}
\end{gathered}
$$

By the ratio of the probabilities of occurrence and not occurred of the event we get natural logarithm, that is logit transformation, and ultimately get the following formula:

$$
\log \operatorname{it}(P)=\ln \left(\frac{P}{1-P}\right)=\beta_{0}+\sum_{i=1}^{n} \beta_{i} x_{i}
$$

$\beta_{0}$ is a constant term, which represents the other under the premise of the argument is 0 , is the natural logarithm by the ratio of the probabilities of occurrence and not occurred of the event; $\beta_{i}$ is the natural logarithm by the ratio of the probabilities of occurrence and not occurred of the event which represents the factor i changes 1 unit and $P \in(0,1)$; $\log i t(P) \in(-\infty,+\infty)$.

\section{FACTORS SELECTED AND ASSUMPTIONS}

By combing the literature can be found, the main factors affecting farmland transfer behavior of family are internal factors and external environmental factors. Internal environmental factors include the personal characteristics of the head of household, family characteristics, labor intensity characteristics, production and management characteristics, property characteristics, etc. External environmental characteristics include credit environment, economic environment, social environment, etc ${ }^{[1]}$. This paper is also related to the factors of farmer wishes, farmer views and market expectations. This paper eventually identifies seven factors including head of household personal characteristic, household characteristics, labor intensity characteristics, production and management features, property characteristics, external environmental characteristics, household willingness, views and market expectations characteristics. We ultimately select 36 variables with specific definitions of variables the same as technical study behavioral variables. Next, we expect the direction of the behavior of each variable on the inflow land to assume, as follows ${ }^{[2-7]}$ : 
TABLE I MODEL VARIABLES AND ASSUMPTIONS DIRECTION

\begin{tabular}{|c|c|}
\hline Variables & $\begin{array}{l}\text { Assumption } \\
\text { s directions }\end{array}$ \\
\hline Age of household head $\left(\mathrm{X}_{1}\right)$ & - \\
\hline Head of household education $\left(\mathrm{X}_{2}\right)$ & $-/+$ \\
\hline Head of household spouse education $\left(\mathrm{X}_{3}\right)$ & $-/+$ \\
\hline The number of labor $\left(\mathrm{X}_{4}\right)$ & $-/+$ \\
\hline The average age of the labor force $\left(\mathrm{X}_{5}\right)$ & + \\
\hline Labor average schooling $\left(\mathrm{X}_{6}\right)$ & $-/+$ \\
\hline Households in the highest degree $\left(\mathrm{X}_{7}\right)$ & $-/+$ \\
\hline The burden of the number of children $\left(\mathrm{X}_{8}\right)$ & $-/+$ \\
\hline The number of non-health $\left(\mathrm{X}_{9}\right)$ & - \\
\hline Labor annual work-months $\left(\mathrm{X}_{10}\right)$ & - \\
\hline Labor intensity per capita $\left(\mathrm{X}_{11}\right)$ & - \\
\hline Whether a single crop $\left(\mathrm{X}_{12}\right)$ & $-/+$ \\
\hline The main planting paddy $\left(\mathrm{X}_{13}\right)$ & $-/+$ \\
\hline Sown area $\left(\mathrm{X}_{14}\right)$ & + \\
\hline Single piece of land scale $\left(\mathrm{X}_{15}\right)$ & $-/+$ \\
\hline Plains accounting $\left(\mathrm{X}_{16}\right)$ & $-/+$ \\
\hline Low-yield farmland area accounted for $\left(\mathrm{X}_{17}\right)$ & $-/+$ \\
\hline Whether plowing land $\left(\mathrm{X}_{18}\right)$ & $-/+$ \\
\hline Agricultural product prices $\left(\mathrm{X}_{19}\right)$ & + \\
\hline Mechanization level $\left(\mathrm{X}_{20}\right)$ & + \\
\hline Average powered of used farm $\left(\mathrm{X}_{21}\right)$ & + \\
\hline Subsidies for arable land scale $\left(\mathrm{X}_{22}\right)$ & + \\
\hline Net income of households $\left(\mathrm{X}_{23}\right)$ & + \\
\hline Food income accounted $\left(\mathrm{X}_{24}\right)$ & - \\
\hline Wages income accounted $\left(\mathrm{X}_{25}\right)$ & - \\
\hline Whether located village with plains $\left(\mathrm{X}_{26}\right)$ & $-/+$ \\
\hline $\begin{array}{l}\text { Growth period of crops where the village } \\
\text { located }\left(\mathrm{X}_{27}\right)\end{array}$ & $-/+$ \\
\hline Whether the access to loans $\left(\mathrm{X}_{28}\right)$ & + \\
\hline Whether the access to internet $\left(\mathrm{X}_{29}\right)$ & $-/+$ \\
\hline Whether the small towns built $\left(\mathrm{X}_{30}\right)$ & - \\
\hline $\begin{array}{l}\text { Whether the enterprises located in the } \\
\text { village }\left(X_{31}\right)\end{array}$ & - \\
\hline $\begin{array}{l}\text { Whether the farmers are willing to work in } \\
\text { future }\left(\mathrm{X}_{32}\right)\end{array}$ & - \\
\hline Whether the farmers should cultivate land $\left(\mathrm{X}_{33}\right)$ & - \\
\hline Grain income-increasing possibilities $\left(\mathrm{X}_{34}\right)$ & + \\
\hline Grain risks $\left(\mathrm{X}_{35}\right)$ & - \\
\hline $\begin{array}{l}\text { Grain income above the wage income }\left(\mathrm{X}_{36}\right) \\
\text { Whether it will expand the land scale in future } \\
\text { (Y) }\end{array}$ & + \\
\hline
\end{tabular}

\section{DATA ACQUISITION AND PROCESSING}

The data in this section is a total of 626 households visited for the survey collated which is derived from five cities including 10 counties (districts) in Heilongjiang province.

\section{MODEL ANALYSIS AND DISCUSSION}

This section is also selected multivariate logistic model to analyze the relevant data, taking regression analysis to analyze the willingness of farmers on land inflows. We finally obtain the following results:

The factors of land inflow willingness are drawn from the analysis: -2 Log likelihood is 557.586, the accuracy rate of model prediction reaches $80.8 \%$, Cox \& Snell R2 is 0.370, Nagelkerke R2 is 0.499 . The fitting result is acceptable, basically meets the needs of analysis. The need to fit with the expected results remains the same. The value of Chi-square model is 289.358 and sig. $=0.000$. This explains it has been mixed through the test of model coefficients. We select 36 relevant variables on the stage of assumption, after model screening 18 variables have been retained. Variable Specifically: age of household head $\left(\mathrm{X}_{1}\right)$, the number of labor $\left(\mathrm{X}_{4}\right)$, the burden of the number of children $\left(\mathrm{X}_{8}\right)$, labor intensity per capita $\left(\mathrm{X}_{11}\right)$, whether a single crop $\left(\mathrm{X}_{12}\right)$, sown area $\left(\mathrm{X}_{14}\right)$, plains accounting $\left(\mathrm{X}_{16}\right)$, whether plowing land $\left(\mathrm{X}_{18}\right)$, average powered of used farm $\left(\mathrm{X}_{21}\right)$, subsidies for arable land scale $\left(\mathrm{X}_{22}\right)$, food income accounted $\left(\mathrm{X}_{24}\right)$, whether located village with plains $\left(\mathrm{X}_{26}\right)$, growth period of crops where the village located $\left(\mathrm{X}_{27}\right)$, whether the access to internet $\left(\mathrm{X}_{29}\right)$, whether the enterprises located in the village $\left(\mathrm{X}_{31}\right)$, whether the farmers should cultivate land $\left(\mathrm{X}_{33}\right)$, grain income-increasing possibilities $\left(\mathrm{X}_{34}\right)$ and grain income above the wage income $\left(\mathrm{X}_{36}\right)$.

The first is the personal characteristics of the head of household. Age of household head $\left(\mathrm{X}_{1}\right)$ has been into the final model. Head of household education $\left(\mathrm{X}_{2}\right)$ and head of household spouse education $\left(\mathrm{X}_{3}\right)$ are excluded from the model. Age of household head $\left(\mathrm{X}_{1}\right)$ coefficient is -0.434 , and it is significance at the level of $5 \%$. This indicates that it has a negative effect on the willingness to land inflow, which is expected to be reversed. Plausible explanation is that the older the head of household, household labor capacity decreased. Thereby they are not willing to expand the operation scale, and even reduce the size of the field.

The second is family characteristics. The number of labor $\left(\left(\mathrm{X}_{4}\right)\right.$ and the burden of the number of children $\left(\mathrm{X}_{8}\right)$ have been into the final model. The average age of the labor force $\left(\mathrm{X}_{5}\right)$, labor average schooling $\left(\mathrm{X}_{6}\right)$, households in the highest degree $\left(\mathrm{X}_{7}\right)$ and the number of non-health $\left(\mathrm{X}_{9}\right)$ are excluded from the model. The number of labor $\left(\mathrm{X}_{4}\right)$ coefficient is -0.422 , and it is significant at the level of $5 \%$. The burden of the number of children $\left(\mathrm{X}_{8}\right)$ coefficient is 0.321 and it is significant at the level of $5 \%$.

The third is the labor intensity characteristics. Labor intensity per capita $\left(\mathrm{X}_{11}\right)$ has entered the final model and labor annual work-months $\left(\mathrm{X}_{10}\right)$ is excluded from the model. Labor intensity per capita $\left(\mathrm{X}_{11}\right)$ coefficient is 0.634 , and it is significant at the level of $1 \%$, this indicates it has a positive impact on the willingness to land inflow. The higher labor intensity per capita, the farmers are more willing to increase land inflows, which is expected to assume the opposite. Possible explanation is that the higher labor intensity 
per capita, farmers will be more and more hard-working, and farmers' planting experience on agriculture is more relatively abundant, so they are more willing to expand the scale of planting.

The fourth is the household production and management characteristics. Whether a single crop $\left(\mathrm{X}_{12}\right)$, sown area $\left(\mathrm{X}_{14}\right)$, plains accounting $\left(\mathrm{X}_{16}\right)$ and whether plowing land $\left(\mathrm{X}_{18}\right)$ have been into the final model, The main planting paddy $\left(\mathrm{X}_{13}\right)$, single piece of land scale $\left(\mathrm{X}_{15}\right)$, low-yield farmland area accounted for $\left(\mathrm{X}_{17}\right)$, agricultural product prices $\left(\mathrm{X}_{19}\right)$ and mechanization level $\left(\mathrm{X}_{20}\right)$ are excluded from the model. Whether a single crop $\left(\mathrm{X}_{12}\right)$ coefficient is 1.354 and it is significant at the level of $1 \%$. This indicates it has a positive impact on the willingness to land inflows. The farmers who plant a single crop are more willing to increase land inflows than farmers who own non single crop, which is expected to assume the same. Sown area $\left(\mathrm{X}_{14}\right)$ coefficient is 0.253 , and it is significant at the level of $1 \%$. Plains accounting $\left(\mathrm{X}_{16}\right)$ coefficient is 0.353 , and it is significant at the level of $1 \%$. Whether plowing land $\left(\mathrm{X}_{18}\right)$ coefficient is 0.638 , and it is significant at the level of $1 \%{ }^{[8]}$.

The fifth is the family property characteristics. Average powered of used farm $\left(\mathrm{X}_{21}\right)$ and subsidies for arable land scale $\left(\mathrm{X}_{22}\right)$ have been into the final model. Average powered of used farm $\left(\mathrm{X}_{21}\right)$ coefficient is 0.545 , and it is significant at the level of $1 \%$. Subsidies for arable land scale $\left(\mathrm{X}_{22}\right)$ coefficient is -0.143 , and it is significant at the level of $1 \%$, which is expected to assume the opposite. Possible explanation is that the larger subsidies of arable land scale for farmers, even if the farmers do not grow food, subsidies they received are more relatively substantial ${ }^{[9]}$. Under the premise of stable income subsidies, farmers are more willing to transfer employment to seek more interests, so they are reluctant to increase land inflows.

The sixth is the family income characteristics. Food income accounted $\left(\mathrm{X}_{24}\right)$ has been into the final model. Net income of households $\left(\mathrm{X}_{23}\right)$ and wages income accounted $\left(\mathrm{X}_{25}\right)$ are excluded from the model. Food income accounted $\left(\mathrm{X}_{24}\right)$ coefficient is -0.212 , and it is significant at the level of $1 \%$. This explains it has a negative impact on the willingness to land inflows. And the larger food income accounted for farmers, they are more reluctant to increase land inflows, which is expected to assume the same.

The seventh is the external environmental characteristics. Whether located village with plains $\left(\mathrm{X}_{26}\right)$, growth period of crops where the village located $\left(X_{27}\right)$, whether the access to internet $\left(X_{29}\right)$ and whether the enterprises located in the village $\left(\mathrm{X}_{31}\right)$ have been into the final model. Whether the access to loans $\left(\mathrm{X}_{28}\right)$ and whether the small towns built $\left(\mathrm{X}_{30}\right)$ are excluded from the model.
TABLE II . MODEL ESTIMATION RESUlTS

\begin{tabular}{|c|c|c|c|c|}
\hline Variables & $\mathrm{B}$ & Wald & $\mathrm{df}$ & Sig. \\
\hline Age of household head & -0.434 & 4.965 & 1 & 0.026 \\
\hline The number of labor & -0.422 & 4.967 & 1 & 0.026 \\
\hline $\begin{array}{l}\text { The burden of the number of } \\
\text { children }\end{array}$ & 0.321 & 3.859 & 1 & 0.049 \\
\hline Labor intensity per capita & 0.634 & 40.447 & 1 & 0.000 \\
\hline Whether a single crop & 1.354 & 14.459 & 1 & 0.000 \\
\hline Sown area & 0.253 & 18.237 & 1 & 0.000 \\
\hline Plains accounting & 0.353 & 32.495 & 1 & 0.000 \\
\hline Whether plowing land & 0.638 & 5.768 & 1 & 0.016 \\
\hline $\begin{array}{l}\text { Subsidies for arable land } \\
\text { scale }\end{array}$ & -0.143 & 14.885 & 1 & 0.000 \\
\hline $\begin{array}{l}\text { Average powered of used } \\
\text { farm }\end{array}$ & 0.545 & 23.345 & 1 & 0.000 \\
\hline Food income accounted & -0.212 & 9.702 & 1 & 0.002 \\
\hline $\begin{array}{l}\text { Whether located village with } \\
\text { plains }\end{array}$ & -1.574 & 16.882 & 1 & 0.000 \\
\hline $\begin{array}{l}\text { Growth period of crops } \\
\text { where the village located }\end{array}$ & -0.394 & 5.208 & 1 & 0.022 \\
\hline $\begin{array}{l}\text { Whether the access to } \\
\text { internet }\end{array}$ & 1.553 & 27.832 & 1 & 0.000 \\
\hline $\begin{array}{l}\text { Whether the enterprises } \\
\text { located in the village }\end{array}$ & -1.565 & 27.565 & 1 & 0.000 \\
\hline $\begin{array}{l}\text { Whether the farmers should } \\
\text { cultivate land }\end{array}$ & -0.765 & 6.402 & 1 & 0.011 \\
\hline $\begin{array}{l}\text { Grain income-increasing } \\
\text { possibilities }\end{array}$ & 0.696 & 24.123 & 1 & 0.000 \\
\hline $\begin{array}{l}\text { Grain income above the } \\
\text { wage income }\end{array}$ & 0.237 & 3.308 & 1 & 0.069 \\
\hline Constant & -7.007 & 23.712 & 1 & 0.000 \\
\hline Forecast accuracy & $80.8 \%$ & & & \\
\hline -2 Log likelihood & 557.58 & & & \\
\hline Cox \& Snell R Square & 0.370 & & & \\
\hline Nagelkerke R Square & 0.499 & & & \\
\hline Chi-square & $\begin{array}{l}289.35 \\
0.000\end{array}$ & & & \\
\hline
\end{tabular}

The eighth is household willingness, views and market expectations characteristics ${ }^{[10]}$. Whether the farmers should cultivate land $\left(\mathrm{X}_{33}\right)$, grain income-increasing possibilities $\left(\mathrm{X}_{34}\right)$ and grain income above the wage income $\left(\mathrm{X}_{36}\right)$ have been into the final model. Whether the farmers are willing to work in future $\left(\mathrm{X}_{32}\right)$ and grain risks $\left(\mathrm{X}_{35}\right)$ are excluded from the model away. The coefficient of whether the farmers should cultivate land $\left(\mathrm{X}_{33}\right)$ is -0.765 , and it is significant at the level of $1 \%$. This indicates it has a negative impact on the willingness to land inflows. Namely, farmers who believe the farmers should cultivate land than farmers who do not agree with this point of view are more reluctant to increase land inflows, which is consistent with expectations hypothesis. The coefficients of grain income-increasing possibilities $\left(\mathrm{X}_{34}\right)$ and grain income above the wage income $\left(\mathrm{X}_{36}\right)$ are 0.696 and 0.237 , respectively; and they are significant at the level of $5 \%$ and $10 \%$, respectively, which indicate that the two variables have a positive effect on the willingness to land inflows. 


\section{CONCLUSIONS}

(1) The variables which have a positive impact on willingness to land inflows as follows: the burden of the number of children $\left(\mathrm{X}_{8}\right)$, labor intensity per capita $\left(\mathrm{X}_{11}\right)$, whether a single crop $\left(\mathrm{X}_{12}\right)$, sown area $\left(\mathrm{X}_{14}\right)$, plains accounting $\left(\mathrm{X}_{16}\right)$, whether plowing land $\left(\mathrm{X}_{18}\right)$, average powered of used farm $\left(\mathrm{X}_{21}\right)$, whether the access to internet $\left(\mathrm{X}_{29}\right)$, grain income-increasing possibilities $\left(\mathrm{X}_{34}\right)$ and grain income above the wage income $\left(\mathrm{X}_{36}\right)$.

(2) The variables which have a negative impact on willingness to land inflows as follows: age of household head $\left(\mathrm{X}_{1}\right)$, the number of labor $\left(\mathrm{X}_{4}\right)$, subsidies for arable land scale $\left(\mathrm{X}_{22}\right)$, food income accounted $\left(\mathrm{X}_{24}\right)$, whether located village with plains $\left(\mathrm{X}_{26}\right)$, growth period of crops where the village located $\left(\mathrm{X}_{27}\right)$, whether the enterprises located in the village $\left(\mathrm{X}_{31}\right)$ and whether the farmers should cultivate land $\left(\mathrm{X}_{33}\right)$.

\section{ACKNOWLEDGMENT}

The paper is funded by the following items. $\mathrm{PhD}$ Research Project Started of Harbin University of Commerce (14rw10); the paper is funded by Science and Technology Project of Heilongjiang Provincial Education Department (1254b007). This paper is the phase progress of Philosophy and Social Science Project of Heilongjiang Province "Policy Combination and Supporting Measures of Rural Land Transfer (item number 14B115) ". This paper is supported by Science
Research Foundation of Northeast Agricultural University (item number 2012RCB77).

\section{REFERENCES}

[1] Liu Yaosen, Dynamic analysis on agricultural prices and farmers income growth $[\mathrm{J}]$ Contemporary Economic Research, 2012 (5) 43- 47

[2] Wang Yue, Xu Wenjuan. Restrictive factors and countermeasures on farmers' income [J].Rural Economy, 2009 (12): 91 - 93

[3] Chen Yin'e, Xing Naiqian, Shi Wenming, Impact of rura infrastructure investment on farmers' income - An empirical study based on dynamic panel data model $[\mathrm{J}]$ Journal of Zhongnan University of Economics and Law, 2012 (1): 97- 102

[4] Fang Junxiong, Empirical research for expenditure impacting on farmers' income [J], Economic Research, 2012 (10): 42

[5] Chul-Woo Kwon, Peter Orazem, Daniel Otto. Off-farm labor supply responses to permanent and transitory farm income [J] Agricultural Economics \& Resource Management, 2006, Vol.34 (1):59-67.

[6] Lou Sha, Liu Huiping, Zhang Dehua. Comparative study on grain production and farmers' income coordination in Heilongjiang [J]. Research of Agricultural Modernization. 2013, Vol.34 (6):654-658

[7] Patton M. P, Kostov, S, McErlean, and J Moss. Assessing The Influence of Direct Payments On The Rental Value O Agricultural Land [J]. Food Policy. 2008, Vol. 33(5): 397-405.

[8] Zhang Dehua. Study on influential factors and countermeasures of farmers' income in Heilongjiang [M]. Harbin: Northeast Agricultural University, 2013.

[9] Cao Yukun, Chen Jiancheng, Chen Lirong. Game analysis on subject behaviors and policies in state-owned forest tenure reform in Yichun [J]. Issues in Agricultural Economy, 2010(5):89-95.

[10] Wang Chengzong, An empirical analysis of factors affecting farmers' income in Henan [J] Chinese Agricultural Science Bulletin, 2012, 28 (20): 226 - 229. 